УДК 65.014.12

\title{
СТРУКТУРНІ МОДЕЛІ ОРГАНІЗАЦІЇ МАРКЕТИНГОВОЇ ДІЯЛЬНОСТІ НА ПІДПРИЕМСТВІ
}

DOI: $10.32620 /$ cher.2021.1.10

Постановка проблеми. Розглядаються питання щодо проектування організаційної структури управління маркетинговою діяльністю підприємства. Метою статті є розгляд теоретичних засад побудови маркетингових управлінських структур і розроблення структурних моделей організації маркетингової діяльності підприємства із застосуванням теорії системного аналізу. Методологічною основою дослідження стали логічні методи обробки інформації, методи системного аналізу та моделювання систем, абстрактно-логічний метод для формулювання висновків. Основна гіпотеза дослідження полягає в тому, що для побудови ефективної організаційної структури управління маркетинговою діяльністю підприємства можна використовувати методи системного аналізу, зокрема процесний та системний підхід. Виклад основного матеріалу. Розглянуто теоретикометодологічні засади побудови маркетингових організаційних структур. Проаналізовано зміни, які відбулися в підходах до управління маркетинговою діяльністю підприємства. Гнучкість, адаптивність, стійкість функціонування системи управління, а також узгодженість поведінки всіх ії елементів, забезпечення високої ефективності управління маркетинговою діяльність залежать від організаційної структури маркетингового управління підприємством. Запропоновано комплекс взаємозалежних структурних моделей системи маркетингового управління підприємством, використання якого дасть змогу підвищити ефективність організації маркетингової діяльності підприємства. Оригінальність та практична значимість дослідження підтверджується можливістю використання запропонованого комплексу структурних моделей як практичного інструмента для проектування організаційної структури маркетингової діяльності підприємства будь-якого типу. Запропоновані розробки можуть бути використані як елемент практичного керівництва до реалізації проектів впровадження маркетингового менеджменту на підприємстві. Висновки та перспективи подальших досліджень. Запропоновані правила та сукупність відповідних структурних моделей можна використати для побудови процесної моделі, що показує послідовність робіт для реалізації функцій маркетингового підрозділу підприємства. Далі за допомогою матричної проекції між функціональною й процесною моделями можна проводити аналіз процесів системи управління маркетинговою діяльністю підприємства.

Ключові слова:

організаційна структура, системний підхід, маркетингова діяльність.

${ }^{1}$ Бондарєва Тетяна Іванівна, канд. екон. наук, доцент, доцент кафедри менеджменту, Національний аерокосмічний університет ім. М. С. Жуковського «Харківський авіаційний інститут», м. Харків, Україна.

Bondareva Tetyana, Ph.D in Economics, Associate professor of the Management Department, National Aerospase University «Kharkiv Aviation Institute», Kharkiv, Ukraine.

ORCID ID: 0000-0002-1834-8174

e-mail: bond_tat@ukr.net

${ }^{2}$ Баришева Катерина Володимирівна, студент спеціальності 073 «Менеджмент», Національний аерокосмічний університет ім. М. Є. Жуковського «Харківський авіаційний інститут», м. Харків, Україна.

Barysheva Kateryna, Student of 073 Management Speciality, National Aerospase University «Kharkiv Aviation Institute», Kharkiv, Ukraine.

ORCID ID: 0000-0002-2815-4429

e-mail: k.v.barysheva@ student.khai.edu

${ }^{3}$ Коломієць Карина Володимирівна, студент спеціальності 073 «Менеджмент», Національний аерокосмічний університет ім. М. С. Жуковського «Харківський авіаційний інститут», м. Харків, Україна.

Kolomiets Karina, Student of 073 Management Speciality, National Aerospase University «Kharkiv Aviation Institute», Kharkiv, Ukraine.

ORCID ID: 0000-0002-2132-9855

e-mail: k.v.kolomiets@student.khai.edu 


\section{STRUCTURAL MODELS OF ORGANIZATION OF MARKETING ACTIVITY AT THE ENTERPRISE}

Formulation of the problem. Questions concerning designing of organizational structure of management of marketing activity of the enterprise are considered. The purpose of the article is to consider the theoretical foundations of construction of marketing management structures and the development of structural models of marketing activities of the enterprise using the theory of systems analysis. The methodological basis of the study were logical methods of information processing, methods of systems analysis and modeling of systems, abstractlogical method for formulating conclusions. The main hypothesis of the study is that to build an effective organizational structure for managing the marketing activities of the enterprise, you can use methods of systems analysis, including process and system approach. Presenting main material. Theoretical and methodological bases of construction of marketing organizational structures are considered. The changes that have taken place in the approaches to the management of marketing activities of the enterprise are analyzed. Flexibility, adaptability, stability of the management system, as well as the consistency of the behavior of all its elements, ensuring high efficiency of marketing management depend on the organizational structure of marketing management of the enterprise. A set of interdependent structural models of the marketing management system of the enterprise is proposed, the use of which will increase the efficiency of the organization of marketing activities of the enterprise. The originality and practical significance of the study is confirmed by the possibility of using the proposed set of structural models as a practical tool for designing the organizational structure of marketing activities of any type of enterprise. The proposed developments can be used as an element of practical guidance for the implementation of marketing management projects in the enterprise. Conclusions and prospects for further research. The proposed rules and a set of appropriate structural models can be used to build a process model that shows the sequence of works to implement the functions of the marketing department of the enterprise. Then, with the help of a matrix projection between the functional and process models, it is possible to analyze the processes of the management system of marketing activities of the enterprise.

\section{Key words:}

organizational structure, system approach, marketing activities.

\section{СТРУКТУРНЫЕ МОДЕЛИ ОРГАНИЗАЦИИ МАРКЕТИНГОВОЙ ДЕЯТЕЛЬНОСТИ НА ПРЕДПРИЯТИИ}

Постановка проблемы. Рассматриваются вопросы проектирования организационной структуры управления маркетинговой деятельностью предприятия. Целью статьи является рассмотрение теоретических основ построения маркетинговых управленческих структур и разработка структурных моделей организации маркетинговой деятельности предприятия с применением теории системного анализа. Методологической основой исследования стали логические методы обработки информации, методы системного анализа и моделирования систем, абстрактно-логический метод для формулирования выводов. Основная гипотеза исследования состоит в том, что для построения эффективной организационной структуры управления маркетинговой деятельностью предприятия можно использовать методы системного анализа, в частности процессный и системный подход. Изложение основного материала. Рассмотрены теоретикометодологические основы построения маркетинговых организационных структур. Проанализированы изменения, которые произошли в подходах к управлению маркетинговой деятельностью предприятия. Гибкость, адаптивность, устойчивость функционирования системы управления, а также согласованность поведения всех ее элементов, обеспечение высокой эффективности управления маркетинговой деятельностью зависят от организационной структуры маркетингового управления предприятия. Предложен комплекс взаимосвязанных структурных моделей системы маркетингового управления предприятием, использование которого позволит повысить эффективность организации маркетинговой деятельности предприятия. Оригинальность и практическая значимость исследования подтверждается возможностью использования предложенного комплекса структурных моделей как практического инструмента для проектирования организационной структуры маркетинговой деятельности предприятия любого типа. Предложенные разработки могут быть использованы как элемент практического руководства к реализации проектов внедрения маркетингового менеджмента. Выводы и перспективы дальнейших исследований. Предложенные правила и совокупность соответствующих структурных моделей можно использовать для построения процессной модели, которая показывает последовательность работ для реализации функций маркетингового подразделения предприятия. Далее с помощью матричной проекции между функциональной и процессной моделями можно проводить анализ процессов системы управления маркетинговой деятельностью предприятия.

Ключевые слова:

организационная структура, системный подход, маркетинговая деятельность. 
Постановка проблеми. Фінансовий успіх будь-якої організації у більшості випадків залежить від іiі маркетингової діяльності. В сучасних умовах господарювання ефективний маркетинг стає життєво необхідним елементом успіху в бізнесі. Більш того, змінився сам підхід до виконання маркетингових функцій. Якщо раніше маркетингові дії зводилися лише до просування продукції на ринку та охоплювали тільки ті підрозділи, які мали відношення до реалізації товарів та послуг, то наразі маркетингове управління поширюється на всі підрозділи підприємства, починаючи від фінансів і виробництва, і закінчуючи сервісними службами і післяпродажним обслуговуванням.

Ці зміни, що відбулися в підходах до маркетингового управління підприємства, обумовлені, в першу чергу, зміною ставлення виробників до поняття якості продукції. Якщо раніше якісною вважалась та продукція, яка в повному обсязі могла виконувати свою функціональну приналежність і відповідала вимогам, стандартам, документально затвердженим значенням певних показників, то зараз діє підхід найбільш повного задоволення потреб споживачів. Тому маркетингові функції необхідно виконувати ще на етапі розроблення характеристик продукції, потім ії виготовлення i пропонування покупцю. Загалом можна виділити кілька основних змін, що відбулися в маркетинговому середовищі:

перехід від маркетингу в маркетинговому відділі до маркетингу у всій організації (тобто цим повинні займатися не тільки маркетологи, торговий персонал i співробітники відділу обслуговування, а й кожний співробітник компанії, оскільки він має також опосередкований вплив на покупця);

підхід до організації маркетингу не за товарними одиницями, а за споживчими сегментами;

відмова від стратегії тільки збереження старих ринкових позицій, та перехід до пошуку нових (на ринках 3 жорсткою конкуренцією компанії повинні постійно рухатися вперед, розробляючи маркетингові програми, випускаючи нові товари і послуги, підтримуючи контакт з покупцями і відстежуючи їх потреби);

зміна пріоритету матеріальних активів на нематеріальні (значна частка ринкової вартості компанії відноситься до нематеріальних активів: торгова марка, клієнти, персонал, ділові зв'язки 3 дистриб'юторами і постачальниками, інтелектуальний капітал тощо);
- $\quad$ зміна підходу до створення брендів не за допомогою реклами, а за допомогою позитивного іміджу, високих результатів діяльності і інтегрованих комунікацій зі споживачами;

необхідність концентрувати увагу не на прибуткових операціях, а прагнути до довічної прибутковості шляхом максимально повного задоволення потреб споживача на обраному сегменті.

Усі ці зміни обумовили необхідність переходу до нових форм організації маркетингової діяльності на підприємстві - до необхідності впровадження маркетингового менеджменту в діяльність організації.

Можна виділити декілька варіантів організації маркетингу 3 урахуванням останніх тенденцій його розвитку як з позицій науки, так і практики. При побудові організаційної структури маркетингового управління необхідно враховувати, що на даний час маркетинг перетворився з однієї з функцій відділу збуту в найважливішу функціональну компоненту, поширену у всій організації. Тому особливої актуальності набирають питання організації маркетингової діяльності на підприємстві 3 одночасним впровадженням принципів маркетингового управління.

Аналіз останніх досліджень i публікацій. Для загального описання маркетингової діяльності підприємства і визначення напрямків іiї подальшого розвитку можна використовувати системний і процесний підходи. Системний підхід підтримує вертикальну координацію різних ієрархічних контурів управління, починаючи зверху від стратегічного планування до оперативного керівництва діяльністю підприємства [1]. Процесний підхід дає можливість здійснювати горизонтальну координацію, тобто зв'язати інформаційні і матеріальні потоки підприємства, визначити ролі його співробітників у кожному процесі [2 - 3].

На практиці питання використання теорії систем і системного аналізу для побудови організаційних структур управління розглядались такими авторами, як Месарович М., Денисов А.О., Кондратьєв В.В., Бурков В.М. тощо. Однак, незважаючи на безліч наукових публікацій з питань розроблення організаційних структур управління підприємствами, сфера їхнього застосування при організації маркетингової діяльності підприємства в умовах впровадження методології маркетингового менеджменту залишається маловивченою.

Таким чином, метою статті $\epsilon$ розгляд теоретичних засад побудови маркетингових управлінських структур i розроблення 
структурних моделей організації маркетингової діяльності підприємства із застосуванням теорії системного аналізу.

Виклад основного матеріалу дослідження. Принципи організації маркетингових підрозділів визначаються маркетинговими особливостями управління, спрямуванням організаційних структур на забезпечення ефективної маркетингової діяльності. Так, можна назвати такі принципи побудови маркетингових організаційних структур: за виконуваними функціями, за географічною ознакою, за управлінням товарами або торговими марками, за управлінням ринками, в матричній формі або за корпоративно-дивізіональним принципом [5].

Найпоширенішою формою організації маркетингової діяльності на підприємстві $€$ функціональна. Як приклад на рисунку 1 наведемо організаційну структуру за функціональною ознакою. Тут п'ять функціональних фахівців підпорядковані віце-президенту з маркетингу. Також до процесів здійснення маркетингових функцій можуть бути залучені менеджер 3 обслуговування покупців, менеджер 3 планування маркетингу, менеджер 3 ринкової логістики, менеджер з інтернет-маркетингу або прямого маркетингу тощо. Безперечно однією 3 головних переваг такої організації маркетингової діяльності є іiі простота та зрозуміла підпорядкованість. Однак при значному розширенні ринків збуту та збільшенні асортименту продукції ефективність такої моделі значно знижується.

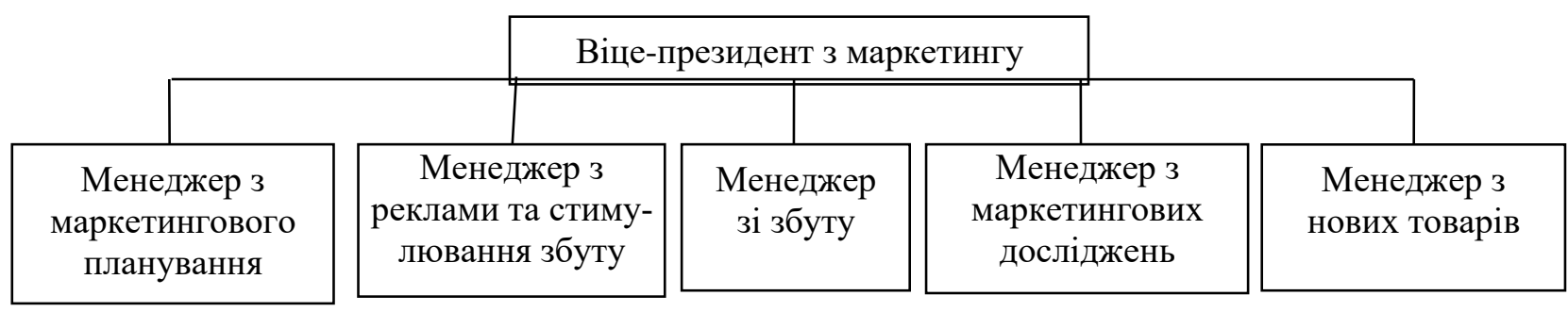

Рисунок 1 - Схема розподілу функціональних обов'язків менеджерів 3 маркетингу Джерело: розроблено авторами на підставі [4]

Нові інформаційні технології і методи маркетингових досліджень, а також розширення торговельних ринків у регіональному аспекті зумовлюють необхідність застосування географічного принципу при організації маркетингової діяльності. Прикладом такої організаційної структури є схема, наведена на рисунку 2.

Як додатковий рівень управління до функціональної організації в компаніях, де виготовляється безліч товарів або торгових марок, використовують принцип організації маркетингової діяльності за товарами або торговими марками. Такий тип організаційної структури доцільний в тих випадах, коли компанія випускає широкий асортимент продукції, але в межах функціональної організації налагодити ефективну систему управління дуже складно. Більш того, можна назвати декілька переваг організації маркетингу за товарами або торговими марками: можливість концентрації зусиль менеджера на розробленні ефективного маркетингового комплексу для свого товару, більш швидка реакції на ринкові виклики, можливість приділяти більше уваги маловідомим торговим маркам. В такій структурі менеджер 3 товару або торгової марки функціонально пов'язаний 3 різними відділами (рисунок 3), що значно роз- ширює його повноваження, функції і можливості щодо просування свого товару.

Організація управління маркетинговою діяльність за ринковим принципом подібна до товарної, де обов'язки менеджерів 3 ринків аналогічні обов'язкам менеджерів 3 товарів. Ця структура має такі ж властивості, недоліки і переваги. Єдиною відмінністю $є$ масштаби об'єкту управління, тобто ефективність роботи менеджера 3 ринку оцінюється за показниками прибутковості відповідних ринків, а не товарних груп.

Часто організації, що мають таку структуру маркетингу, перетворюються на організації, орієнтовані на певний ринок.

Якщо компанії мають значну кількість асортиментних груп товарів і працюють на різних ринках, то вони можуть створювати матричні структури управління маркетинговою діяльністю.

Основною перевагою матричних організацій $є$ простота i згуртованість команд навколо певних бізнес-процесів, які можуть охоплювати відразу декілька функціональних підрозділів. Однак така структура має численні недоліки в питаннях розподілу повноважень i відповідальності. 


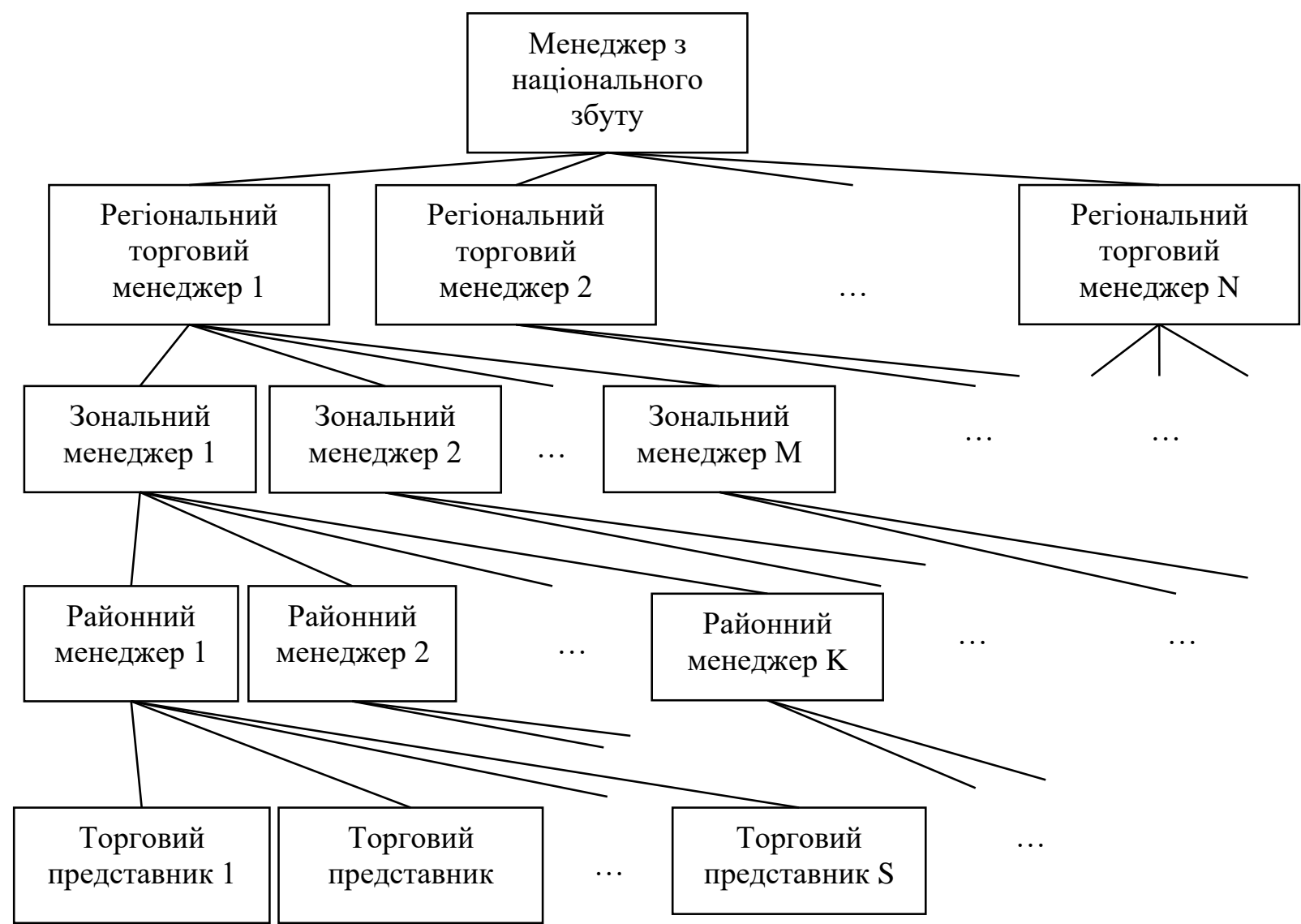

Рисунок 2 - Структура організації маркетингової діяльності Джерело: розроблено авторами на підставі [4]

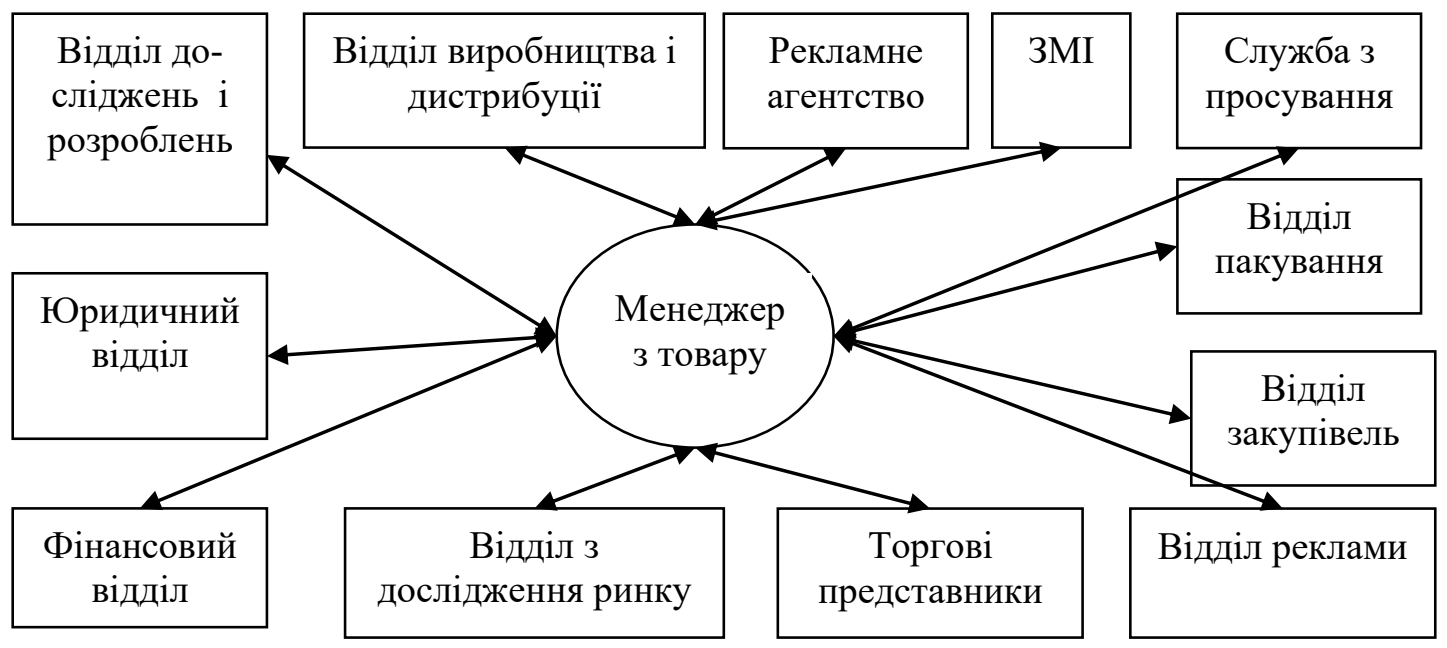

Рисунок 3 - Взаємодія менеджера з товару при організації управління маркетингом за товарами Джерело: розроблено авторами на підставі [4]

Якщо компанія швидко розширюється, збільшуючи стрімко асортимент продукції і кількість ринків збуту, часто відбувається перетворення основних товарно-ринкових груп на окремі підрозділи. В такому випадку мова йде про корпоративно-дивізіональну організацію.
При побудові будь-якої організаційної структури маркетингової діяльності необхідно враховувати, що всім відділам треба брати до уваги вимоги споживачів і працювати спільно задля задоволення їхніх потреб.

Алгоритм створення маркетингового підрозділу на підприємстві складається 3 таких етапів [6]: 1) розроблення поточної і пер- 
спективної системи цілей і завдань компанії у галузі маркетингу; 2) розроблення системи критеріїв і обмежень зі створення служби маркетингу; 3) розроблення ряду варіантів моделі організаційної структури служби маркетингу на підприємстві; 4) оцінки варіантів, вибору і обгрунтування організаційної маркетингової структури; 5) деталізація вибраної моделі організаційної структури маркетингу; 6) реорганізації організаційної структури й інших підсистем управління підприємством; 7) розроблення інформаційного, ресурсного забезпечення, системи планування, реалізації i контролю; 8) обгрунтування кадрового складу і штатного розкладу; 9) затвердження документів, що регламентують діяльність служби маркетингу; 10) контроль за процесом адаптації системи управління маркетингом і підприємства в цілому (контроль впровадження).

У роботі [7] було запропоновано використовувати системний підхід для побудови організаційної структури управління підприємством. Візьмемо за основу запропонований комплекс моделей і побудуємо моделі типового підрозділу управління маркетинговою діяльністю. За допомогою наведених правил створення організаційних структур управління підприємства побудуємо такі структурні моделі.

Таблиця 1 - Цілі маркетингового управління на підприсмстві

\begin{tabular}{|c|c|}
\hline Групи цілей & Цілі \\
\hline $\begin{array}{l}\text { 1. Цілі відносно ін- } \\
\text { формаційного забез- } \\
\text { печення маркетин- } \\
\text { гового менеджменту }\end{array}$ & $\begin{array}{l}\text { 1.1. Забезпечення збирання, класифікації, аналізу, оцінки, накопичення та } \\
\text { розповсюдження актуальної, своєчасної й точної інформації } \\
\text { 1.2. Вдосконалення процесів планування, реалізації і контролю маркетинго- } \\
\text { вих заходів } \\
\text { 1.3. Забезпечення ухвалення обгрунтованих маркетингових рішень для } \\
\text { зменшення комерційних ризиків і отримання конкурсних переваг }\end{array}$ \\
\hline $\begin{array}{l}\text { 2. Цілі зі створення } \\
\text { комплексу } \\
\text { «маркетинг - мікс» }\end{array}$ & $\begin{array}{l}\text { 2.1. Забезпечення зростання продажу на внутрішньому/зовнішньому ринках } \\
\text { 2.2. Задоволення потреб носіїв платоспроможного попиту на внутрішньому } \\
\text { та зовнішньому ринках } \\
\text { 2.3. Зниження витрат виробництва за рахунок оптимального використання } \\
\text { можливостей підприємства та його резервів розвитку } \\
\text { 2.4. Одержання планового прибутку за рахунок більш повного використання } \\
\text { потенціалу підприємства }\end{array}$ \\
\hline $\begin{array}{l}\text { 3. Цілі стосовно ор- } \\
\text { ганізації маркетин- } \\
\text { гової діяльності }\end{array}$ & $\begin{array}{l}\text { 3.1. Забезпечення злагодженості, узгодженості і високої продуктивності } \\
\text { спільної маркетингової діяльності }\end{array}$ \\
\hline $\begin{array}{l}\text { 4. Цілі стосовно } \\
\text { планування і кон- } \\
\text { тролю маркетинго- } \\
\text { вої діяльності }\end{array}$ & $\begin{array}{l}\text { 4.1. Забезпечення високого рівня досягнення запланованих результатів } \\
\text { діяльності підприємства } \\
\text { 4.2. Підвищення ефективності маркетингової діяльності за рахунок макси- } \\
\text { мального використання компанією можливостей щодо ринків, продуктів і } \\
\text { каналів збуту }\end{array}$ \\
\hline
\end{tabular}

Джерело: розроблено авторами
1. Цільова модель. Як вихідні дані для формування цільової моделі управління маркетинговою діяльністю підприємства будемо використовувати склад цілей, наведених у

2. Функціональна модель. Як вихідні дані для формування функціональної моделі управління маркетинговою діяльністю підприємства будемо використовувати склад функцій, наведений у табл. 2.

3. Модель організаційної структури. Як вихідні дані для формування моделі організаційної структури управління маркетинговою діяльністю підприємства будемо використовувати склад структурних елементів, наведений у табл. 3 [8].

Для встановлення взаємозв'язку між моделями системи управління маркетинговою діяльністю підприємства введемо такі матричні проекції:

1. Матрична проекція між цільовою й функціональною моделями (Навіщо? Що?), яка встановлює відповідність функцій цілям. Як вихідні дані для формування матричної проекції між цільовою й функціональною моделями маркетингового підрозділу підприємства будемо використовувати: склад цілей підрозділу; склад функцій, необхідних для досягнення цілей підрозділу; закріплення функцій за цілями підрозділу. табл. 1. 
Таблиця 2 - Функції системи маркетингового управління на підприємстві

\begin{tabular}{|c|c|}
\hline Групи функцій & Функції \\
\hline $\begin{array}{l}\text { 1. Функції } \\
\text { менеджменту }\end{array}$ & $\begin{array}{l}\text { 1.1. Організація функціонування маркетингового підрозділу } \\
\text { 1.2. Організація взаємодії між основними учасниками маркетингової діяльності, а } \\
\text { також розподіл відповідальності за виконання певних функцій. } \\
\text { 1.3. Участь у подальшому розвитку маркетингової діяльності підприємства і } \\
\text { вдосконалення його організаційної структури. } \\
\text { 1.4. Формування плану і бюджету маркетингового підрозділу. } \\
\text { 1.5. Аналіз ефективності функціонування маркетингового підрозділу. }\end{array}$ \\
\hline $\begin{array}{l}\text { 2. Функції } \\
\text { управління } \\
\text { маркетинговою } \\
\text { діяльністю }\end{array}$ & $\begin{array}{l}\text { 2.1 Збір необхідної інформації і проведення маркетингових досліджень ринку } \\
\text { 2.2. Сегментація ринку і оцінка конкурентів } \\
\text { 2.3. Розробка продукту (дизайн, торгова марка, упаковка, інновації) } \\
\text { 2.4. Розроблення цінової стратегії і ціноутворення } \\
\text { 2.5. Планування товарного руху і вибір каналів розподілу продукції } \\
\text { 2.6. Планування реклами, складання рекламного бюджету і оцінка ефективності } \\
\text { рекламних дій } \\
\text { 2.7. Складання відносин з потенційними покупцями і стимулювання збуту } \\
\text { 2.8. Робота із засобами масової інформації і формування іміджу компанії } \\
\text { 2.9. Розробка, впровадження і контроль маркетингової стратегії }\end{array}$ \\
\hline $\begin{array}{l}\text { 3. Допоміжні } \\
\text { функції }\end{array}$ & $\begin{array}{l}\text { 3.1. Узгодження і контроль інформації, що надходить з інших підрозділів } \\
\text { підприємства } \\
\text { 3.2. Розроблення стандартних процедур управління маркетинговою діяльністю і } \\
\text { регламентування дій маркетологів. } \\
\text { 3.3. Розроблення і удосконалення корпоративних методик виконання } \\
\text { маркетингових фунццй. } \\
\text { 3.4. Ведення баз даних, нагромадження і зберігання необхідної маркетингової } \\
\text { інформації } \\
\text { 3.5. Навчання співробітників і менеджерів підприємства методології } \\
\text { маркетингового управління }\end{array}$ \\
\hline
\end{tabular}

Джерело: розроблено авторами

Таблиця 3 - Структурні елементи системи маркетингового управління

\begin{tabular}{|l|l|}
\hline \multicolumn{1}{|c|}{ Рівні управління } & \multicolumn{1}{|c|}{ Штатні посади } \\
\hline 1. Вищий стра- & 1.1. Заступник генерального директора з маркетингу (віце-президент, комерцій- \\
маркетингового & ний директор) \\
управління & 1.2. Маркетинг-директор (керівник служби, відділу, департаменту маркетингу); \\
\hline 2. Середній рівень & $\begin{array}{l}\text { 2.1. Менеджер з маркетингу } \\
\text { 2.2. Менеджер продукту }\end{array}$ \\
& 2.3. Менеджер з продажу, збуту, каналам розподілу \\
& 2.4. Менеджер по роботі із споживачами, клієнтами \\
& 2.5. Менеджер з реклами \\
& 2.6. Менеджер по підтриманню зв'язків з громадськістю \\
\hline 3. Оперативно- & 3.1. Торговий агент, представник, промоутер \\
виконавчий & 3.2. Агент по рекламі \\
(тактичний) рівень & 3.3. Асистент менеджера з маркетингу \\
& 3.4. Продавці \\
\hline 4. Технічний рівень & 4.1. Менеджер (інструктор, спеціаліст) по навчанню персоналу (стандартизова- \\
& ним прийомам маркетингової діяльності з урахуванням особливостей ринку і \\
& підприємства) \\
& 4.2. Контролер маркетингу \\
\hline Допоміжний рівень & 4.3. Менеджер з маркетингових досліджень \\
& 4.4. Економіст-аналітик, маркетолог (забезпечує внутрішній аудит маркетингу) \\
& 4.5. Інтерв'юер \\
& 4.6. Спеціаліст з комп'ютерної обробки маркетингової інформації \\
\hline
\end{tabular}


Далі побудуємо матричну проекцію між цільовою й функціональною моделями (табл. 4 , де "+" означає необхідність виконання функції для досягнення певної мети), за допомогою якої можна проводити функціональний аналіз системи управління за такими напрямками:

- чи за всіма цілями закріплені функції підрозділу;

- чи необхідно розширити склад функції підрозділу;

- виконання скількох функцій необхідно для досягнення кожної мети функціонування підрозділу;

- чи достатньо функцій, закріплених за певною метою підрозділу;

- чи є зайві функції, закріплені за певною метою;

- чи відповідають функції, закріплені за певною метою, можливості іiі досягнення.
2. Матрична проекція між функціональною моделлю й моделлю організаційної структури (Що? Хто?), яка встановлює відповідальність структурних елементів за виконання функцій. Як вихідні дані для формування матричної проекції між функціональною моделлю й моделлю організаційної структури системи управління маркетинговою діяльністю підприємства будемо використовувати:

- склад функцій підрозділу підприємства;

- склад структурних елементів (посад), необхідних для виконання функцій;

- закріплення структурних елементів (посад) за функціями.

Однак таку проекцію можна побудувати тільки для конкретної організаційної структури маркетингового управління 3 визначеними посадами.

Таблиця 4 - Закріплення функцій за цілями системи управління маркетинговою діяльністю

\begin{tabular}{|c|c|c|c|c|c|c|c|c|c|c|}
\hline $\begin{array}{c}\text { Цілі } \\
\text { Функції }\end{array}$ & 1.1. & 1.2. & 1.3. & 2.1. & 2.2. & 2.3. & 2.4. & 3.1. & 4.1. & 4.2. \\
\hline 1.1 & & & & & & & + & + & & + \\
\hline 1.2. & & & + & & & & & + & & \\
\hline 1.3 & & + & & & & & & & & \\
\hline 1.4 & & + & + & & & & & & & \\
\hline 1.5 & & & & & & & & & + & + \\
\hline 2.1 & + & & & + & & & & & & \\
\hline 2.2 & & & & & + & & & & & \\
\hline 2.3 & & & & & + & + & & & & \\
\hline 2.4 & & & & & & & + & & & \\
\hline 2.5 & & + & & & & & & & & \\
\hline 2.6 & & & + & & & & & & & \\
\hline 2.7 & & & + & + & + & & & & & \\
\hline 2.8 & + & & & & & & & + & & \\
\hline 2.9 & & + & & & & & & & + & + \\
\hline 3.1 & + & & & & & & & + & & \\
\hline 3.2 & & & + & & & & & & & + \\
\hline 3.3 & & & + & & & & & + & & \\
\hline 3.4 & + & & & & & & & & & \\
\hline 3.5 & & + & & & & & & & & + \\
\hline
\end{tabular}

Джерело: розроблено авторами

За допомогою матричної проекції між функціональною моделлю й моделлю організаційної структури можна проводити структурно-функціональний аналіз системи управління маркетинговою діяльністю підприємства за такими напрямками:

- чи за всіма функціями підрозділу закріплені структурні елементи;

- чи необхідні додаткові структурні елементи для виконання функцій підрозділу;
- чи є зайві структурні елементи, що не беруть участь у виконанні функцій;

- яка завантаженість структурних елементів, що беруть участь у виконанні функцій.

Крім цього матрична проекція між функціональною моделлю й моделлю організаційної структури дозволяє розробити положення про підрозділи підприємства, що містить склад цілей, функцій, структурних елементів, закріплення функцій за структур- 
ними елементами, а також посадові інструкції співробітників маркетингового підрозділу.

Висновки та перспективи подальших досліджень. Таким чином, для забезпечення високої ефективності управління маркетинговою діяльністю підприємства слід сформувати комплекс структурних взаємозалежних моделей системи управління, за допомогою яких можна вирішувати такі завдання: 1) проводити структурнофункціональний аналіз різних варіантів організації маркетингової діяльності підприємства; 2) вибирати найкращі варіанти побудови нової або вдосконалення існуючої організаційної структури управління маркетинговою діяльністю підприємства; 3) розробляти необхідну організаційнорозпорядницьку документацію, іiї положення, регламенти й посадові інструкції; 4) забезпечувати автоматизоване виконання основних функцій управління маркетинговою діяльністю підприємства.

Як напрямок подальших досліджень можна рекомендувати на базі запропонованих вище правил побудувати процесну модель (Як?), що показує послідовність робіт для реалізації функцій підрозділу. За допомогою матричної проекції між функціональною й процесною моделями можна проводити аналіз процесів системи управління маркетинговою діяльністю підприємства за такими напрямками: 1) чи за всіма функціями закріплені процеси; 2) чи необхідні додаткові процеси для реалізації функцій маркетингового підрозділу; 3) чи є зайві процеси, що не беруть участь у реалізації функцій; 4) скільки процесів бере участь у реалізації кожної функції і яка їхня взаємодія; 5) чи відповідають процеси, закріплені за певною функцією, цілі ії реалізації.

\section{Лтература}

1. Мессарович М., Такахара И. Общзая теория систем. Математические основы. Москва: Мир, 1978. 312 с.

Стаття надійшла

до редакції : 25.01.2021 p.
2. Бурков В. Н., Ириков В. А. Модели и методы управления организационными системами. Москва: Наука, 1994. 234 с.

3. Маркетинговий менеджмент: підручник / Ф. Котлер, К.Л. Келер, А.Ф. Павленко. Київ: Видавництво «Хамджест», 2008. 720 с.

4. Frederick E. Webster Jr. The Role of Marketing and the Firm. Handbook of Marketing. Edited by Barton A. Weitz and Robin Wensley. London: Sage Publications, 2002. P. 39-65.

5. Гайдаенко Т. А. Маркетинговое управление. Полныли курс МВА. Принциипь управленческих решений и российская практи$\kappa a$. Москва: Эксмо, 2006. 496 с.

6. Бондарєва Т. І. Застосування системного підходу для побудови організаційної структури управління підприємством. Часопис економічних реформ. 2020. № 4 (40). С. 85-91.

7. Пелішенко В. П. Маркетинговий менеджмент: навч. посіб. Київ: Центр навчальної літератури, 2003. 200 c.

\section{References}

1. Messarovich, M., Takahara, I. (1978). General theory of systems. Mathematical bases. Moscow: Mir, 312.

2. Burkov, V., Irikov V. (1994). Models and methods of management of organizational systems. Moscow: Science, 234.

3. Kotler, F., Keler, K. L., Pavlenko, A. F. (2008). Marketing management. Kyiv: Vidavnistvo "Hamjest", 720.

4. Frederick, E. Webster, Jr. (2002) The Role of Marketing and the Firm. Handbook of Marketing. Edited by Barton A. Weitz and Robin Wensley. London: Sage Publications, 39-65.

5. Gaidaenko, T. A. (2006). Marketing management. Complete MBA course. Principles of management decisions and Russian practice. Moscow: Eksmo, 496.

6. Bondarieva, T. I. (2020). Stagnation of the systemic approach to induce the organizational structure of enterprise management. Time description of economic reform, 4(40), 85-91.

7. Pelishenko, V. P. (2003). Marketing management. Kyiv: Center for Naval Literature, 200.

Стаття прийнята

до друку: 29.03.2021 p.

\section{Бібліографічний опис для цитування :}

Бондарєва Т. І. Структурні моделі організації маркетингової діяльності на підприємстві / T. І. Бондарєва, К. В. Баришева, К. В. Коломієць // Часопис економічних реформ. - 2021. № 1 (41). - C. 82-90. 